Journal of

Media, Culture \& Society

\title{
A cultural shock doctrine? Austerity, the neoliberal state and the creative industries discourse
}

\begin{tabular}{|c|c|}
\hline Journal: & Media Culture and Society \\
\hline Manuscript ID: & Draft \\
\hline Manuscript Type: & Original Article \\
\hline Keyword: & $\begin{array}{l}\text { creative industries, cultural industries, cultural policy, neoliberalism, } \\
\text { coalition, political economy }\end{array}$ \\
\hline Abstract: & $\begin{array}{l}\text { A number of writers have made the argument that the development } \\
\text { creative industries policy discourse in the UK and elsewhere represents the } \\
\text { articulation of a politics that is neoliberal in character. The marginalisation } \\
\text { of Blairism in favour of Cameronism in the UK, and the Coalition } \\
\text { Government's adoption of an ever more explicit neoliberal dogma in its } \\
\text { radical restructuring/dismantling of the welfare state, provides the } \\
\text { opportunity to evaluate this argument. } \\
\text { The article summarises the creative industries policy discourse and the } \\
\text { main research paradigms that have been used to interrogate it. From there } \\
\text { it explores a number of discursive positions that have placed pressure on } \\
\text { policy actors and explores their institutionalisation in policy structures since } \\
\text { 2008. It is argued that the major institutional policy frameworks of the } \\
\text { creative industries discourse have proved remarkably durable through the } \\
\text { current phase of neoliberal restructuring of the state. At the same time, } \\
\text { discursive pressure is being exerted from a reactionary cultural } \\
\text { conservatism that seeks to further undermine and delegitimate the socially } \\
\text { and politically progressive elements of the creative industries discourse. }\end{array}$ \\
\hline
\end{tabular}




\section{Introduction}

A number of writers, myself included, have made the argument that the development and adoption of the 'creative industries' as official policy and structural organisation in the media, cultural and technology sectors in the UK and elsewhere represents, in a number of concrete ways, the articulation of a politics that is neoliberal in character. ${ }^{1}$ While there are important variations in this argument, it essentially suggests that in the post-1997 period the British New Labour and other governments (particularly Australia) followed, at least in part, a political trajectory first embarked upon by the Thatcherite New Right in the 1980s. The marginalisation of Blairism in favour of Cameronism in the UK, and the Coalition Government's adoption of an ever more explicit neoliberal dogma in its radical restructuring/dismantling of the welfare state, provides the opportunity to evaluate this argument. If it is correct, we might expect little qualitative variation from the overall trajectory of creative industries policy since 2010, accounting for external factors. On the other hand, variation and transformation in the Coalition's approach to the institutional and organisational structure, the funding models and the wider discursive field of the creative industries can reveal much about this new conjuncture in political economy and the wider social and cultural forces that have come into play to shape cultural production and participation in Britain.

A broad definition of cultural policy would include "the promotion or prohibition of cultural practices or values by governments, corporations, other institutions and individuals." (Throsby 2010: 8) This article explores continuity and transformation in cultural policy through an analysis of the creative industries policy discourse after the great financial crisis of 2008 and the change of government in the UK. It begins by summarising the creative industries policy discourse and the main research paradigms that have been used to interrogate it. From there it explores a number of discursive positions that have placed pressure on policy actors and explores their institutionalisation in policy structures. Finally, conclusions are drawn as to the lines of continuity and transformation in the creative industries discourse. The argument is made that the major institutional policy frameworks of the creative industries discourse as established and refined during the New Labour period have proved remarkably durable through the current phase of neoliberal restructuring of the state. At the same time, discursive pressure is being exerted from a reactionary cultural conservatism that seeks to further undermine the socially and politically progressive elements of the creative industries discourse, as in other areas of the state.

\section{The creative industries and neoliberalism}

There are many useful discussions of the emergence of the creative industries as a flagship culturaleconomic initiative from the New Labour policy incubators whilst in opposition in the 1990s. One recent account describes it in the following way:

Creative industries as a concept was consistent with a number of touchstones of the redefining of the British Labour Party as 'New Labour', as it was spearheaded by Tony Blair and his supporters within Labour, with its recurring concerns with economic modernization and Britain's post-industrial future. Its focus on the role of markets as stimuli to arts and culture was consistent with the notion of a 'Third Way' between Thatcher-era free market economics and traditional social democracy, which was 
nonetheless more accommodating of the role of markets and global capitalism than traditional British Labour Party philosophy and doctrine. (Flew 2012: 14)

The newly formed Department of Culture, Media and Sport established the parameters of the creative industries and situated their significance as key drivers within the wider British economy. Of particular importance to the development of government interventions in the form of policy was the perceived 'spill-over' relationship between core creative activities (the creation of cultural expression in books, paintings, films, plays and so on), the industries of commercialisation and reproduction (publishing, galleries and museums, DVD distribution, the West End etc.), and the wider economy (see, for example, Throsby 2001; or more recently Hopkins 2010).

The main consequence of this innovation was that it foreground the perceived economic role of what used to be called 'the arts', which in turn allowed a range of public subsidy mechanisms to be seen as investment into the commercial economy, and to a lesser extent, into social welfare. It also allowed the values and practices of the private sector to increasingly determine the organisation and management of the cultural sector, with the market assuming a much greater proportion of the role of cultural commissioning and authority than had been the case previously, and a much greater role in the management and regulation of productive capital in the form of ideas and labour ('creativity'), which fitted well with New Labour's political investment in neoliberal capitalism and big business.

On one level this represents a further step along the ideological road begun in the 1980s towards the disarticulation of cultural production from romantic and idealist conceptions of art (see Garnham 1990) which many commentators would view as generally welcome. Indeed, most research on this process identifies the major incoherence in the creative industries policy discourse as the unresolved tensions between the traditions of the arts and culture, and those of media and communications; the tensions between romantic idealism and economy, or between instrumentalism and aesthetics (see, for example, Hesmondhalgh and Pratt 2005) - the very stuff of academic debate, particularly from a cultural studies perspective.

There have been a number of trenchant critiques of creative industries as a policy concept. For example, Philip Schlesinger has characterised 'creativity' as a particularly banal doctrine increasingly hegemonic across a number of policy fields (Schlesinger 2007); Eleanora Belfiore has critiqued the claims made about the economic and social value of the creative industries in New Labour cultural policy-making as having no relationship with empirical reality ('bullshit') (Belfiore 2009); and Kate Oakley has questioned the instrumental use of cultural policy as an unconvincing panacea to social and economic exclusion (Oakley 2006).

There are also a number of responses that investigate the creative industries policy discourse in relation to political economy, particularly the globalisation and neo-liberalisation of national economies from the 1980s (Miller 2004; Garnham 2005; Hesmondhalgh 2005; McGuigan 2005; Freedman 2008). For example, Nicholas Garnham's influential discussion situates the creative industries as an unconvincing attempt to artificially link the arts and culture to information and communication technologies (ICTs), and the post-Fordist information society:

This is important because the shift to the terminology "creative industries" has taken place, and can only be understood and assessed, in the context of a wider debate about the impact of information and communication technologies (ICTs) and digitalisation and 
the relationship between the deployment of new communication networks and the products and services carried over them. In short, policy towards the "creative industries" can no longer be separated from ICT policy in its various forms and the wider information society perspective within which that policy is formulated. (20)

One thing to emerge is the importance of the creative industries discourse to the management and organisation of labour in the cultural and media sectors, with the resultant contradictions of freedom, exploitation and inequality, and this has proved a particularly fruitful line of research (Banks 2007; Banks and Hesmondhalgh 2009; Banks 2010; McGuigan 2010; Deuze 2011; Hesmondhalgh and Baker 2011).

My own contribution emphasises the symbolic function of the SME and the small independent producer as central to wider processes of casualization and marketization in the creative industries discourse, in turn part of a shift of material and cultural authority from labour to capital that is at the core of the neoliberal project (removed by the author 2012).

On this level, the discourse of the creative industries is an example of the centrality of the state to the actual processes of neoliberalisation, with the cultural welfare state being gradually incorporated into the market economy. If that sounds like a reductive statement, it must be emphasised that this is a dynamic and incomplete process that contains a range of mechanisms, from the construction of new institutional structures, instrumental initiatives in training, funding in higher education and the wider cultural sector, to methods to casualise and discipline labour, to inculcate a new way of thinking about 'creativity' and the 'creative worker', to install processes developed within the market as the only legitimate relationships between cultural production and consumption, to the straightforward privatisation of cultural organisations and resources. Whilst a neoliberal political economy is determining the agenda and setting the parameters of cultural policy and practice, the precise ways in which this is negotiated in any given context is determined by a range of relatively autonomous forces.

This is a debate that has far reaching consequences. To name a few: how to understand the political economy of neoliberalism in relation to contemporary cultural policy? How to characterise the New Labour (and other Third Way Left-of-centre parties) phenomenon in relation to marketization in cultural production? How to locate a progressive politics within contemporary cultural policy and practice? Answers to these questions are important because they inform a response to the radical Right restructuring and dismantling of public services, including cultural provision, in the UK and elsewhere.

These questions notwithstanding, the creative industries discourse has become inexorably embedded across a range of institutions in national and local government, in education and training, in language and in academic research, with an increasing international scope (see Flew 2012: 9-27). The creative industries, then, are one of New Labour's key legacies and the major contribution of Blairism to culture, the residual architecture of Cool Britannia.

How has the discourse of the creative industries faired since the great financial crisis of 2008 and the change of government in the UK? The remainder of this article will outline and critique the development of an austerity cultural policy, in terms of the discursive construction of the role of the state in culture by policy actors and the right-wing press, and then in terms of concrete policy 
interventions. The aim is to explore some of the forces shaping cultural policy and practice in the UK, and those likely to do so in the future.

\section{The Coalition and Culture}

Policy discourses are understood as "patterns in social life, which not only guide discussions, but are institutionalised in particular practices" (Hajer and Laws, 2006, quoted in Flew 2012: 11). Policy studies that employ discourse analysis often seek to identify and critique the range of accepted concepts, assumptions, categories, values, and so forth, which inform the decisions of policy actors. However, a policy discourse may display more or less coherence, be subject to many or few competing claims, and there may be significant distance between the language and narratives used to discursively construct certain actions as legitimate and their subsequent institutionalisation in official or corporate structures.

If the creative industries is an example of a particularly robust, successfully institutionalised and increasingly global policy discourse - even as its efficacy and integrity is disputed - the question becomes, to what extent and in what ways have its central themes, values and practices been contested, modified and transformed since 2008? What does this tell us about the adaptability of the discourse to austerity and the contemporary neoliberal state?

Prior to the 2010 General Election, Shadow Culture Secretary Jeremy Hunt went to lengths to demonstrate continuity between the approach of the Conservative Party and that of New Labour:

People have had an assumption about Conservative governments partly because of some of the things that happened in the 1980s and partly because of the tone of some of the debate around the arts in the 1980s, which appeared to say public spending on the arts was something you might progressively want to reduce, which isn't where the modern Conservative party stands. We recognise the critical importance of public funding. (Quoted in Higgins 2010)

Upon entering government, however, official rhetoric began to shift, placing less emphasis on the role of the state in the creative industries. For example, the Coalition 'Programme for Government' booklet notes that "Government believes that a vibrant cultural, media and sporting sector is crucial for our well-being and quality of life. We need to promote excellence in these fields, with government funding used where appropriate to encourage philanthropic and corporate investment." (HM Government 2010: 14) Most importantly, it is emphasised that the "deficit reduction programme takes precedence over any of the other measures in this agreement, and the speed of implementation of any measures that have a cost to the public finances will depend on decisions to be made in the Comprehensive Spending Review." (HM Government 2010: 35) The status of the creative industries was unsure: were they a superfluous part of the welfare state and, therefore, to be subject to austerity policies, at the back of the queue behind health, defence, schools, and so on? Or were the creative industries actually part of the British commercial economy, and therefore to be supported as one of the routes out of fiscal bankruptcy?

In October 2010 the Comprehensive Spending Review revealed the extent of the cuts that were to be made to public funding for culture over the next four years. These included: 
- DCMS budget cut by $24 \%$

- Museums and Galleries cut by $15 \%$

- British Film Institute by $15 \%$

- Arts Council of England by $30 \%$

- Creative Partnerships initiative closed

- Creativity, Culture and Education closed

- $15 \%$ cut to Regularly Funded Organisations

- UK Film Council closed

- Regional Screen Agencies closed

- Regional Development Agencies closed

(HM Treasury 2010)

This was followed up in 2013 with a further 7\% cut to DCMS and a 10\% cut to local authority spending, upon which many smaller, regionally-based cultural organisations depend.

These cuts were met with almost uniform hostility from figures in the cultural sector. For example, Nicholas Serota, the Director of the Tate, argued that:

A $10-15 \%$ cut in cash terms over four years would be a challenge of the kind that arts organisations regularly surmount; more than this will threaten the whole ecosystem, cutting off the green shoots with the dead wood, reducing the number of plays and exhibitions, discouraging innovation, risk and experiment and threatening the ability of organisations to earn or raise money for themselves. (Serota 2010)

Arguments promoting the state's role in the cultural economy tended to focus heavily upon the economic and commercial contribution of the creative industries, in line with the assumptions inherent within the discourse. Polly Toynbee in the Guardian is exemplary of the genre:

Labour brought a golden era to the arts after two decades of drought. A $70 \%$ rise in funding began with that symbolic opening-up of free museums and galleries. In the decade to $2007,2 \mathrm{~m}$ new jobs and $\mathrm{f} 16.6 \mathrm{bn}$ in exports were generated by the creative industries [...] anyone serious about rebalancing the economy would look to Britain's creative industries, the second largest sector after finance. Labour showed how a smattering of state money - in all, about $f 1 \mathrm{bn}$ - has been enough seedcorn to grow a giant beanstalk of an industry. (Toynbee 2011)

The disproportionate effects of the cuts on smaller, less commercial, regional or ethnic minority-led organisations, and in turn the narrowing of participation in public culture, was also noted. For example, Topher Campbell, again in the Guardian:

The real damage of the cuts will be inflicted on smaller companies and individuals and those on the fringes with fragile balance sheets. This is where a lot of the companies created and run by black and minority ethnic (BME) artists and producers work [...] However, the bigger issue is the extent to which our country's cultural and intellectual life suffers. Mainstream institutions cannot really represent the range and diversity of voices in BME communities. (Campbell 2011)

The cuts to public funding for the cultural sectors, from this point of view, are both economically illiterate and culturally conservative. However, the cuts to DCMS funding are broadly in line with the more general reductions in state spending across the spectrum of public spending. They do not, 
therefore, suggest a change of status of culture or the creative industries within government priorities and, despite the closure of a number of New Labour institutions, there has not been restructuring and reorganisation of the kind undertook by New Labour from 1997, or of the kind seen on other areas of the state, particularly welfare and the NHS, but also the education system and the military.

Arguments on the other side of this debate tended to centre on three themes, which can be usefully illustrated by the following example. The day after the publication of the Spending Review, Quentin Letts, writing in the Daily Mail, bemoaned the "multicultural nomenklatura of senior lieutenants" at the Arts Council. He continued: "Yes, spending on the arts is being given a haircut, but it will be markedly less severe than in many areas of state spending [...] If we are going to blame anyone, we should perhaps look at the Arts Council and its obsession with political correctness." Letts asked, "Did John Donne have to go on arts awareness seminars in the North-East to show his devotion to 'access'? He did not." Letts argued that the "great creative talents of past centuries relied on the occasional patron and on naked commercial appeal." The cuts to public funding are "a spring prune of the kind private companies undergo every few years, essential to help reduce a disastrous national deficit." For Letts, the cuts are part of a "wider cultural battle that is far too important to ignore." (Letts 2011)

Hyperbole aside, three themes emerge that work to legitimate the cuts to public funding for culture: firstly, a right-wing attack on 'progressive' or liberal cultural initiatives - the idea that under New Labour tax payers' money was distributed to ethnic minorities, women, and so on, at the expense of 'quality'; the second closely related theme is as an attack on unnecessary bureaucracy and 'red tape'; and the third is that a reduced state will stimulate private and philanthropic investment. From this point of view, the cuts to public funding are actually beneficial to British culture, in the same way that the cuts to welfare spending are portrayed as beneficial to the poor. To understand the plausibility of these themes it is necessary to explore their basis in the creative industries discourse in more detail.

The belief that organisations were receiving public money as a response to employing a high proportion of ethnic minorities, women or disabled people has no basis in reality. The problem has always been the under-representation and marginalisation of certain social groups in the cultural sectors. Cultural organisations have consistently failed to reflect the socio-demographics of local communities, audiences and the wider population. Instrumental policies, where they actually existed, were designed to address systemic ethnic, gender and other inequalities by increasing diversity to more equal levels. All the available evidence demonstrates that women, members of ethnic minorities and disabled people are consistently underrepresented in cultural sectors when compared to the working population as a whole (see, for example Skillset 2012). Furthermore, while there may be a perception of reverse discrimination in instrumental funding policies of cultural institutions, the extent to which these kinds of initiatives ever informed the actions of organisations is debatable. For example, a major review of the evidence for the Arts Council in 2010 found that

the received wisdom is that over the last decade government has placed greater emphasis on instrumental outcomes. While there have been new, targeted initiatives in areas such as education, there is little evidence that any prioritisation of social or economic objectives has had any substantial impact on the decisions that have been 
made about mainstream arts funding, or indeed on how artists and arts organisations go about their work. (Bunting 2010: 11)

Richard Hylton goes even further to describe instrumental initiatives in favour of multiculturalism as a form of tokenism that "have arguably exacerbated rather than confronted the exclusionary pathologies of the art world." (Hylton 2007: 131)

The sense that during the New Labour period quality was marginalised in favour of multiculturalism as part of a politically-motivated crusade against the white middle-classes is a myth. Nevertheless, then Culture Secretary Jeremy Hunt used his speech at the Media Festival Arts in London in September 2010 to argue that "We must move on from the box-ticking targets approach, saying if you get a certain number of people from certain backgrounds you can win a certain amount [of funding]". (Quoted in Thomas and Dowell 2010) If, as I have argued elsewhere, one of the key successes of the creative industries discourse was the mobilization of a culturally progressive, politically liberal constituency behind the idea of market-led restructuring (removed by the author 2012), there is now evidence that this constituencey is having its political and cultural influence withdrawn by a reactionary cultural conservatism.

Concerns over instrumentalism and bureaucracy in cultural policy do, however, reflect a longstanding debate over cultural management and policymaking that developed during the New Labour period. Belfiore has traced the roots of instrumentalism in cultural policy to the 1980s and the need for cultural organisations to demonstrate their value in terms of economic objectives as a response to Thatcherism. These arguments were then recycled within a social policy paradigm from the late 1990s, producing the need for organisations and institutions to demonstrate a return on 'investment', in turn producing a near-obsessive focus on the methods and practices of monitoring and evaluation (Belfiore 2002). There is evidence that many of the increases in funding during the New Labour period were ring-fenced or restricted for specific purposes or schemes determined centrally (see, for example, Galloway 2004), increasing the burden of bureaucratic control and management with its attendant need for measurement and evaluation (there is a large literature dedicated to debates within impact measurement and methodology. See, for example, Selwood 2002).

Finally, philanthropy and business sponsorship are offered as an alternative to the use of taxpayer's money. Rena De Sisto, Global Arts and Culture Executive at financial services company Merrill Lynch, articulates the case for business sponsorship of culture:

The government proposes that the arts community adopt the US-based approach to arts funding, with less dependence upon public and more upon private funding sources. In fact, the British arts community already has a tradition of private philanthropic and corporate funding, so the difference with the US is really one of degree. And while the US may be further along the curve, with its longer, more comfortable relationship with private funding for the arts, in both nations the arts sector can benefit from new approaches to working with corporations. Similarly, many types of companies can and do benefit greatly from supporting the arts. But some fundamental changes need to occur to unlock this opportunity. (De Sisto 2010)

In this way, the significance of corporate sponsorship goes beyond a mere funding source to offer a full reconstruction of the role of cultural organisations, one that sees cultural production as servicing 
the perceived needs of companies, as opposed to needs emerging from civil society. De Sisto, for example, argues that arts organisations must allow companies to "extract sound business benefits, such as access for employees, brand visibility and client outreach opportunities." (De Sisto 2010)

This has been reflected in policy, albeit in a relatively minor fashion. In 2011 Jeremy Hunt wrote to dozens of FTSE 100 executives asking them to invest in the arts as part of his 'Year of Corporate Giving' initiative and a new inheritance tax break for those that leave a legacy to cultural organisations was introduced. There have also been a number of reports commissioned to recommend ways of improving fundraising and philanthropy in the cultural sector (for example Sood and Pharoah 2011; Phillips 2012) However, while business sponsorship and philanthropy might be an ideologically-driven aspiration or ideal, as a policy paradigm it is far from convincing and has not to date resulted in any major policy initiative.

Overall, while the attack on bureaucracy and political correctness tap into genuine debates about the cultural management techniques that became prominent during the New Labour period, and particularly the instrumentalisation of cultural funding for social objectives, they have very little empirical basis. Alongside measures to encourage sponsorship and philanthropy, the significance of these themes is as normative projections; much sound and fury without plausible or authentic applications in policy, so far.

Much more significant to an understanding of creative industries policies under austerity are the interventions made to what would have traditionally been called media policy. These include interventions into the media regulatory framework, particularly initiatives to scale back Ofcoms's role and further deregulate broadcasting, the Digital Economy Act (2010) and the Live Music Act (2012). From 2013 the tax break system used to stimulate investment in the film industry since 2007 was extended to include television productions, video games and animation. The government announced investment of $£ 150 \mathrm{~m}$ in the Mobile Infrastructure Project to improve mobile coverage across the UK, investing $f 20 \mathrm{~m}$ to provide broadband internet access to rural communities, and f150m in the Urban Broadband Fund to equip ten cities with faster broadband and wifi. In 2013 Ofcom auctioned the $800 \mathrm{MHz}$ and $2.6 \mathrm{GHz}$ radio spectrum licenses to pave the way for the adoption

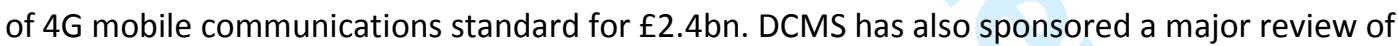
intellectual property and copyright by lan Hargreaves and the Intellectual Property Bill, the Government's response, is, at the time of writing, awaiting its first reading in the House of Commons. Further to this, the Creative Industries Council, chaired by Business Secretary Vince Cable, was set up in 2011. It undertook a two-year review of the media and telecommunications sectors and produced a policy document in 2013 called Connectivity, Content and Consumers.

Taken together, these measures demonstrate the continued importance of technological, legal and regulatory infrastructure to the creative industries discourse with very little observable variation to the previous regime. For example, the Connectivity, Content and Consumers report begins by noting that "Our discussions with industry and others demonstrated that the present framework is broadly working well, supporting economic growth and innovation, and the things that we value as a society" (DCMS 2013: 6).

We can conclude that the role of the state in the management and promotion of an appropriate technical and legal framework for the creative industries continues to be centred on information and communication technologies, digitisation and copyright to the point of seamless continuity with New 
Labour. The institutional structure of the creative industries policy discourse therefore displays a remarkable similarity and continuity to that described by Garnham in 2005.

\section{Conclusion}

Flew has argued that "the future of the creative industries hinges to a significant degree on the view taken towards them by the Conservative-Liberal Democrat coalition". (Flew 2012: 30) As already noted, the main tension identified in the creative industries discourse has always been that between culture and commerce. A clear point that emerges from the above is the degree of space opened up in the discourses of cultural policy between the 'cultural' and the 'industrial', or between the core creative activities of cultural expression and the industries of commercialisation and reproduction, and the wider economy. It is the former that have come under ideological pressure from the Right at the same time as bearing the brunt of the cuts to public funding, while the latter occupy primacy within the creative industries discourse, enjoy continued investment and attention at a high level within government. The question is: does this represent a qualitative change in the creative industries?

The Coalition Government have not had a coherent vision or programme for a cultural policy that differs markedly from the discourse of the creative industries as developed and refined during the New Labour period. Furthermore, despite the initial fears of a slash and burn exercise of seemingly successful New Labour institutions such as the Film Council and the Regional Development Agencies, the main creative industries infrastructure remains largely intact, albeit at substantially reduced levels. The creative industries have not been subject to the sort of ideological attacks and reorganisation that have been witnessed in welfare spending, the NHS or, to a lesser extent, the education system. The cultural landscape under the Coalition is not, therefore, being fundamentally shaped or reshaped by any coherent central initiatives or programs of cultural policy. The key driver of change in the period post-2008 is the austerity agenda, an overarching programme that has very little nuance, but informs all areas of public policy.

Once this factor is taken into consideration, the accepted concepts, assumptions, categories and values of the creative industries policy discourse remain remarkably durable. This is evident across the key areas of institutionalised activity: the tax regime subsidy to creative businesses, telecommunications policy and copyright, and the subsidisation of core cultural activities through the arms-length bodies, albeit at lower levels than pre-2008. At the same time, cultural policy in a broad sense is subject to contestation from a range of reactionary forces that seize the opportunity to further delegitimate the role of the state in distributing resources towards politically progressive practice. This is evidenced across the discursive themes of red tape, multiculturalism and equality, business sponsorship and philanthropy, and the methods of measurement and evaluation.

Susan Galloway and Stewart Dunlop have described the discourse of the creative industries as "rather like a Russian doll; once the layers are discarded at heart it appears an amorphous entity, with no specific cultural content at all." (Galloway and Dunlop 2007: 29) This is an appropriate metaphor to explain the transformation in creative industries policy in the age of austerity: the layers are being pulled away, further sheared of cultural content. 
This is in line with the neoliberal state as it emerges from the 2008 crisis: an acceleration of the process of dismantling the social democratic welfare state and its associated discourses under the disguise of austerity; the continued strengthening of the values and practices of the market as the only legitimate mechanisms for social and cultural action. This analysis suggests that the narrative of the creative industries discourse can be accurately understood as part of a trajectory of the commodification of culture, the continuation of trends that go back to the 1980 s.

The 'shock doctrine' is a term coined by Naomi Klein to describe a strategy employed to mystify the restructuring of national economies along neoliberal lines during periods of crisis, and therefore to circumvent democratic scrutiny (Klein 2007). Is this a useful way to understand cultural policy in the age of austerity? Actually, the dominant policy discourse of the creative industries require very little 'shock therapy' in order to adapt to the current phase of neoliberal crisis management. It was there already.

\section{End Notes}

1. Neoliberalism has become a problematic term. Terry Flew, for example, describes it as particularly elastic, ubiquitous, almost entirely pejorative, and often confused with neo-conservatism. It "has come to be a much-abused term that too easily lends itself to a poorly theorised condemnatory stance that too easily lends itself to whatever happens to be a particular author or presenter's bugbear at that point in time." (2012: 191) In contradistinction to Flew, neoliberalism is used in this article in the way that Des Freedman, drawing upon David Harvey, understands it, as "a profoundly contradictory phenomenon where free-market enthusiasts who sing the praises of open markets subsequently impose tariffs to protect domestic industries, usually for electoral gain". In these terms, neoliberalism is best understood as a project of upwards capital redistribution as opposed to a fundamentalist theoretical conviction in the natural ubiquity and efficacy of unfettered markets. Neoliberalism is therefore a political/ideological project in which the state can play a significant role in creating and preserving an institutional framework appropriate to the purpose of capital redistribution (Freedman 2008, pp. 39-40). This is an important distinction if the term neoliberalism is to have analytical power.

\section{Works Cited}

Banks, M. (2007). The politics of cultural work. Basingstoke, Palgrave Macmillan.

Banks, M. (2010). "Craft labour and creative industries." International journal of cultural policy 16(3): 305-321.

Banks, M. and D. Hesmondhalgh (2009). "Looking for work in creative industries policy." International journal of cultural policy 15(4): 415-430.

Belfiore, E. (2002). "Art as a means of alleviating social exclusion: Does it really work? A critique of instrumental cultural policies and social impact studies in the UK." International journal of cultural policy 8(1): 91-106.

Belfiore, E. (2009). "On bullshit in cultural policy, practice and research: notes from the British case." International Journal of Cultural Policy 15(3): 343-359.

Bunting, C. (2010). Achieving great art for everyone: A review of research and literature to inform the Arts Council's 10-year strategic framework. London, Arts Council England. 
Campbell, T. (2011). "Cutting diversity in the arts will cost Britain dearly." Retrieved 23rd August, 2013, from http://www.theguardian.com/commentisfree/2011/mar/30/diversity-arts-cuts-minoritytheatre.

DCMS (2013). Connectivity, content and consumers: Britain's digital platform for growth. London.

De Sisto, R. (2010). "No pain, no gain: the good news about arts funding cuts." Retrieved 23rd August, 2013, from http://www.theguardian.com/stage/theatreblog/2010/aug/03/arts-fundingbanks-merrill-lynch.

Deuze, M., Ed. (2011). Managing media work. London, SAGE.

Flew, T. (2012). The Creative Industries: Culture and Policy. London, Sage.

Freedman, D. (2008). The Politics of Media Policy. Cambridge, Polity Press.

Galloway, S. (2004). Public spending on the arts in the UK. Glasgow.

Galloway, S. and S. Dunlop (2007). "A critique of definitions of the cultural and creative industries in public policy." International journal of cultural policy 13(1): 17-31.

Garnham, N. (1990). Public Policy and Cultural Industries. Capitalism and Communication. N. Garnham and F. Inglis. London, Sage: 154-168.

Garnham, N. (2005). "From Cultural to Creative Industries: An Analysis of the Implications of the 'Creative Industries' Approach to Arts and Media Policy Making in the United Kingdom." International Journal of Cultural Policy.

Harvey, D. (2005). A Brief History of Neoliberalism. Oxford, Oxford University Press.

Hesmondhalgh, D. (2005). "Media and Cultural Policy as Public Policy: The Case of the British Labour Government." International journal of cultural policy 11(1): 95-109.

Hesmondhalgh, D. and S. Baker (2011). Creative labour: Media work in three cultural industries. London, Routledge.

Hesmondhalgh, D. and A. C. Pratt (2005). "Cultural Industries and Cultural Policy." International journal of cultural policy 11(1): 1-13.

Higgins, C. (2010). "Arts funding 'significantly safer under Tories', says shadow minister." Retrieved 15th August, 2013, from http://www.theguardian.com/culture/2010/feb/22/arts-funding-saferwith-tories-manifesto.

HM Government (2010). The Coalition: Our Programme. London, Cabinet Office: 1-31.

HM Treasury (2010). The Spending Review. London, The Stationary Office: 106.

Hopkins, L. (2010). Innovation by nature: Creative industries, innovation and the wider economy. London, The Work Foundation: 1-21.

Hylton, R. (2007). The Nature of the Beast: Cultural Diversity and the Visual Arts Sector, a Study of Policies, Initiatives and Attitudes 1976-2006. Bath, ICIA.

Letts, Q. (2011). "Squealing luvvies, rich whiteys and why the arts CAN take a haircut without civilisation falling." Retrieved 20th August, 2013, from http://www.dailymail.co.uk/debate/article1371388/Arts-funding-cuts-Why-arts-CAN-haircut-civilisation-falling.html. 
McGuigan, J. (2005). "Neo-Liberalism, Culture and Policy." International Journal of Cultural Policy 11(3): 229-241.

McGuigan, J. (2010). "Creative Labour, Cultural Work and Individualisation." International Journal of Cultural Policy 16(3): 323-335.

Miller, T. (2004). "A view from a fossil: The new economy, creativity and consumption - two or three things I don't believe in." International Journal of Cultural Studies 7(1): 55-65.

Removed by the author

Oakley, K. (2006). "Include us out-Economic development and social policy in the creative industries." Cultural Trends 15(4): 255-273.

Phillips, P. (2012). Philanthropy beyond London. London.

Schlesinger, P. (2007). "Creativity: From Discourse to Doctrine." Screen 48(3): 377-387.

Selwood, S. (2002). "The politics of data collection: Gathering, analysing and using data about the subsidised cultural sector in England." Cultural Trends 12(47): 13-84.

Serota, N. (2010). "A blitzkrieg on the arts." Retrieved 22nd August, 2013, from http://www.theguardian.com/commentisfree/2010/oct/04/blitzkrieg-on-the-arts.

Skillset (2012). Employment census of the creative media industries. London.

Sood, A. and C. Pharoah (2011). Fundraising activity in arts, culture, heritage and sports organisations: a qualitative study. London, DCMS.

Thomas, L. and B. Dowell (2010). "Arts organisations can't rely on using women and ethnic minorities to win public cash." Retrieved 20th August, 2013, from http://www.dailymail.co.uk/news/article$1310585 /$ Arts-organisations-rely-using-women-ethnic-minorities-win-publiccash.html\#ixzzOzXJWaEuO.

Throsby, D. (2001). Economics and Culture. Cambridge, Cambridge University Press.

Throsby, D. (2010). The Economics of Cultural Policy. Cambridge, Cambridge University Press.

Toynbee, P. (2011). "A great act of vandalism that will impoverish us all." Retrieved 23rd August, 2013, from http://www.theguardian.com/commentisfree/2011/mar/28/arts-council-funding-cuts. 